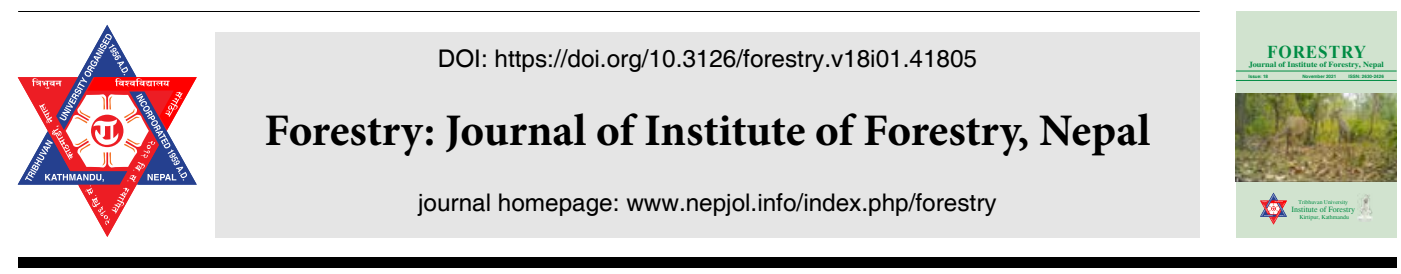

\title{
Status and types of Chiuri (Diploknema butyracea (Roxb.) H.J.Lam) owned by indigenous Chepang Communities in Makwanpur, Nepal
}

\author{
Roshan Chikanbanjar ${ }^{1^{*}}$, Umed K Pun ${ }^{2}$ and Bhola Bhattarai ${ }^{3}$ \\ 1 Central Department of Environmental Science, Tribhuvan University, Kirtipur, Kathmandu \\ 2 Department of Horticulture, Njala University, Freetown, Sierra Leone \\ 3 School of Arts, Kathmandu University, Hattiban, Lalitpur
}

\section{KEYWORDS}

\section{Chiuri}

Types

Khoria

Seed

Chepang

\begin{abstract}
Chiuri (Diploknema butyracea) is a medium-sized tree that inhabits in sub-Himalayan tracks of steep slopes and cliffs at an elevation of 400 to 1400 meters from west to east of Nepal. It belongs to Sapotaceae family of plant kingdom. This study was conducted to assess status of Chiuri tree in Raksirang Rural Municipality (RRM) with particular interest to location, khoria aspect, age and types. Primary data were collected through questionnaire survey, interviews, informal discussion, etc. whereas secondary data were collected through desk review. Biometric data such as seed size and seed count per $\mathrm{kg}$ of seeds were measured using measuring scale and weighing balance. Four types of Chiuri namely Wayo, Lanyo, Titiya and Tomyo were found in RRM depending on ripening time of fruit. Most of them have Chiuri older than 30 years of age and their khoria facing south direction. Chiuri takes 6-10 years to start fruiting from seedling. Based on survey, Wayo and Lanyo were found in lower elevation whereas Titiya and Tomyo were found in higher elevation. The timing of fruit ripening was different but followed a pattern of types located in lower elevation fruiting earlier. However, defoliation timing was different and was not influenced by elevation.
\end{abstract}

\section{Introduction}

The botanical name of common Chiuri found in Makwanpur district of Nepal is Diploknema butyracea (Chikanbanjar et al. 2021). It also has other names such as Aesandra butyracea, Madhuca butyracea. The Chiuri, a mediumsized tree that inhabits in sub-Himalayan tracks of steep slopes and cliffs at an elevation of 400 to
1400 meters from west to east of Nepal, belongs to Sapotaceae family of the plant kingdom (Shukla 2017). The highest population of this tree species is believed to be in mid-western region of Nepal (Shukla 2017) present day parts of Lumbini and Karnali provinces. Nepal has approximately 10.8 million trees of Chiuri geographically distributed in 46 districts of the country (MEDEP 2014) and has potential to 
produce 37,245 MTs Chiuri butter and 17,285 MTs of honey from Chiuri trees (MEDEP 2010). The indigenous Chepangs have a particularly close relationship with the Chiuri tree (Practical Action 2010). People in Chiuri growing areas of Nepal generally do not chop up or fell the Chiuri trees (MEDEP 2010). The Chepang, a minority group of semi-nomadic people consume Chiuri butter (gheu) and conserve the trees. Chepang are able to live in the infertile upper slopes of the Mahabharat hills since they have the knowledge of the use of plants (Rijal 2011). The Chepangs are highly dependent on forest resources, partly for their use and partly for barter and sale (Bhattarai 1995; Chhetri et al. 1997). They are very good at weaving baskets, leaf umbrellas, and other handicrafts. Besides, they also know about wild plants and processing methods to detoxify wild foods (Bhattarai 1995). Leaves of Chiuri is used as a fodder for livestock, the residue of leaves is also used as manure and stems are used as a source of alternative source of fuel (Thapa 2019). Chiuri also has other indirect benefits such as carbon sequestration, food for wild animals like bat and birds, shelter for many birds, Chiuri seed cake is used as pesticides or for fishing etc. Chiuri tree(s) is given as a dowry to the daughter in marriage by the Chepangs (Shakya 2000). Thus, Chiuri trees has significant importance in the economic life of Chepangs but they are yet to take advantage to the fullest potential (Chikanbanjar et al. 2021). However, the information on various types of Chiuri found in Nepal is still very limited such as elevation preference of different types, time to flowering, time to ripening, time to defoliation and size and weight of seeds. This research is therefore designed to study the status of different types of Chiuri trees in RRM including location, aspect of khoria, age, availability of Chiuri types, time to flowering, time to fruit ripening, time to defoliation etc.

\section{Materials and Methods}

\section{Study area}

Raksirang Rural Municipality (RRM) was selected as a study area for this study. RRM has been formed by the decision of the Government of Nepal dated March 10, 2017 by merging the four former VDCs of Kankada, Raksirang, Sarikhet, and Khairang in the western and northern part of Makwanpur district. Chainpur is the headquarter of RRM. We conducted this survey in ward number 6, 7, 8 and 9 of RRM, Makwanpur, Bagmati Province, Nepal. Its latitude is $27^{\circ} 32^{\prime} 53.19^{\prime \prime} \mathrm{N}$ and longitude is $84^{\circ} 50^{\prime} 39.13^{\prime \prime} \mathrm{E}$. The total population of this Rural Municipality is 30830 (RRM 2019). The total area is $226.7 \mathrm{sq} \mathrm{km}$ and the population density is $111.12 \mathrm{sq} \mathrm{km}$ (RRM 2019). The forest cover of RRM is 14,941 ha. (66.1\%) (DFRS 2018). The average temperature in the village is up to $35^{\circ} \mathrm{C}$ throughout the year, a minimum of $5^{\circ} \mathrm{C}$ in winter and $18^{\circ} \mathrm{C}$ on average. As it spreads from an altitude of 300 meters to 2300 meters above sea level, its climate also varies. The climate of Raksirang is of sub tropical to temperate type. It is characterized by mild winters and hot summers. It is hot from March to October and cooler from November to February. The coldest month is December and the hottest month is May. The average annual rainfall is $2200 \mathrm{ml}$. The average annual temperature is $27^{\circ} \mathrm{C}$. It has huge scope for commercial production of Chiuri trees since the land in this area are mostly steep slope and fragile soil texture. The temperate monsoon climate of Raksirang is suitable for Chiuri trees. Many of the local youths could get self-employed or get job opportunities by generating income from selling Chiuri seed, butter (gheu) and honey. Raksirang Rural Municipality lies at the Northwest side of Makwanpur district (Fig. 1). The municipality is mostly inhabited by Chepang and Tamang who directly or indirectly depend on Chiuri and other forest products for their livelihood. Majority of the local people are farmers who depend on subsistence farming.

\section{Methods of Data Collection and Analysis}

Fieldwork was carried out from June 2020 to September 2020. The quantitative data were collected through questionnaire survey 


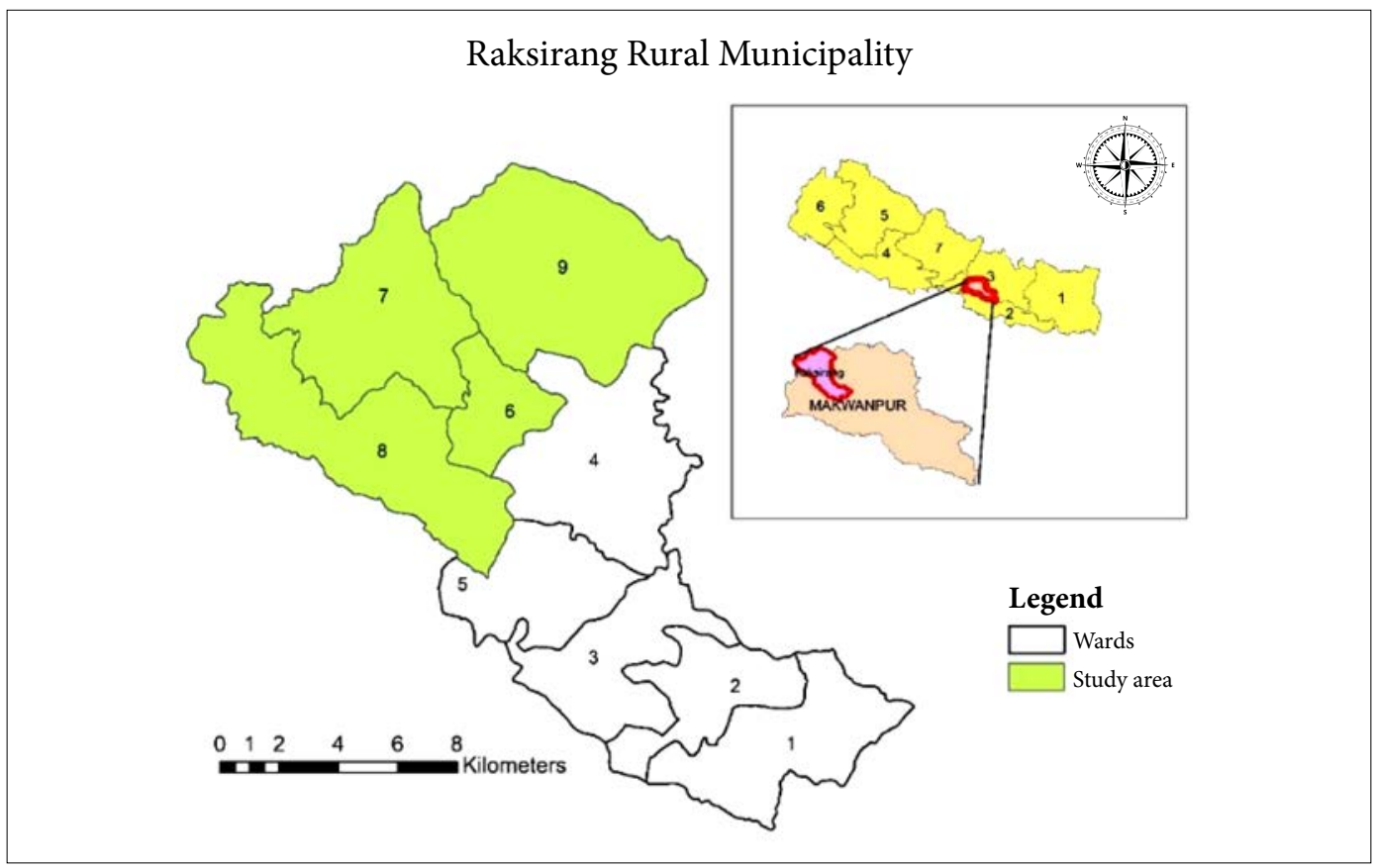

Figure 1: Map of Study area (Source: National Forum for Advocacy, Nepal)

and qualitative data were collected through interviews and informal discussion with the representatives of local government. We interviewed 100 Chepang and Tamang households from four wards of RRM, 25 households in each ward, 15 chairpersons of cooperatives, forest user groups and ward and elderly people were consulted as key persons to cross-check the information. We selected Chepang communities for social survey as the lifestyle of the Chepang communiites are intimately related with Chiuri. They are traditionally conserving these trees and they use it for many purposes like fodder, firewood, timber, butter extraction from its seeds, bee farming and so on. Biometric data such as size and weight of seeds were measured using scale and weighing balance respectively. The dry seeds of already ripe fruits collected from the local people were randomly selected for measurement of size and weight. All the data from the field were entered and analyzed in Microsoft Excel and the results were presented in the form of tables, graphs and charts. The present status of Chiuri trees in RRM was studied based on the knowledge of respondents with regards to location, aspect, time to fruit ripening and age of the tree.

\section{Results and Discussion}

\section{Status of Chiuri trees in RRM}

The survey showed higher percentage of the respondents knew that Wayo and Lanyo were located in the lower elevation whereas Titiya and Tomyo were located in the higher elevation (Table 1). Higher number of respondents (72.5\%) knew that the larger number of Wayo and Lanyo Chiuri trees were located in the lower elevations as compared with the higher elevation. In contrast, higher number of respondents (41.5\%) knew that Titya and Tomyo were located in the higher elevations (Table 1). The early harvesting of Chiuri fruits in lower elevation is quite obvious and is observed in other fruits too such as Mango (Whiley et al. 1989). The factor that drives the early fruiting in lower elevation is due to conducive environment (higher temperature) resulting in 
Table 1: Types of Chiuri found in high or low elevation

\begin{tabular}{ccccccc}
\hline Elevation & Wayo $(\mathbf{n})$ & Lanyo $(\mathbf{n})$ & Mean(\%) & Titiya $(\mathbf{n})$ & Tomyo $(\mathbf{n})$ & Mean $(\%)$ \\
\hline no idea & 8 & 19 & 13.5 & 35 & 37 & 36.0 \\
Low & 77 & 68 & 72.5 & 23 & 22 & 22.5 \\
High & 15 & 13 & 14.0 & 42 & 41 & 41.5 \\
Total & 100 & 100 & 100.00 & 100 & 100 & 100.00 \\
\hline
\end{tabular}

vigorous vegetative growth as was observed in Mango (Whiley et al. 1989) in contrast to higher elevation where the temperature is relatively lower all through the year.

\section{Aspect of khoria (Shifting cultivation)}

More than one-third (37\%) of the respondents had their khoria facing south whereas very less percent $(6 \%)$ was facing north. Similarly, about one-fourth of the respondents had their khoria facing east and west each. This shows that the Chiuri grows well in south face direction followed by west and east direction (Fig. 2) suggesting it needs plenty of sunlight. Many types of fruits prefer similar aspects and yields superior quantity and quality of fruit (Timilsina

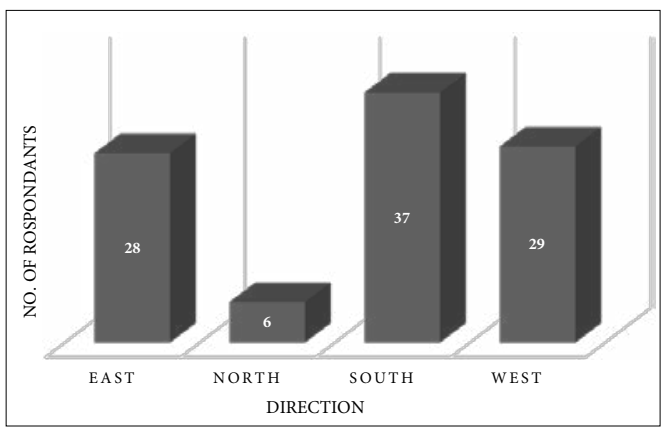

Figure 2: Direction of khoria facing

and Mishra-Tripathi 2019).

\section{Time to fruiting of Chiuri trees:}

More than 60 percent of the respondents said Wayo and Lanyo Chiuri seedlings began fruit production at the age of 6-10 years after plantation while some had no idea of the time to fruit production. Similarly, about 50 percent of the respondents stated that Titiya and Tomyo Chiuri also began fruit production at the age 6-10 years (Table 2 ) but about $40 \%$ had no idea how long it took Chiuri tree to fruit. There are still a very small number who say it may take between 11-15 years to fruit. In general, Chiuri is reported to fruit in 6 years or 10 years.

Table 2: Start of time to fruit production after planting seedlings (year)

\begin{tabular}{lcccc}
\hline \multicolumn{1}{c}{ Years } & Wayo & Lanyo & Titiya & Tomyo \\
\hline no idea & 13 & 26 & 38 & 41 \\
2 to 5 years & 4 & 4 & 5 & 5 \\
6 to 10 years & 65 & 63 & 54 & 51 \\
11-15 years & 18 & 7 & 3 & 3 \\
Total & 100 & 100 & 100 & 100 \\
\hline
\end{tabular}

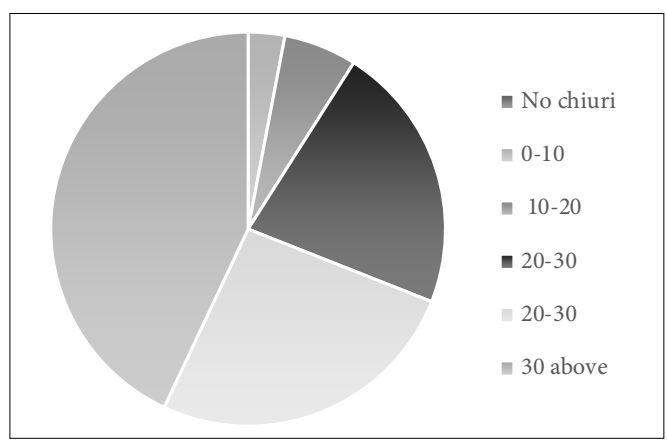

Figure 3: Age range of Chiuri (year)

\section{Age range of Chiuri found in RRM}

According to the survey, forty three percent of respondents had Chiuri tree of age above 30 years whereas 26 percent had Chiuri of age 2030 (Fig. 3). Similarly, twenty two percent of the respondents had Chiuri trees that were between 10-20 years. Thus, $91 \%$ of the respondents had Chiuri trees at fruit bearing age. There were about $3 \%$ who didn't own any Chiuri trees whereas about $6 \%$ owned young Chiuri trees below 10 years. The vast majority of the population having Chiuri trees testifies the 
cultural and economic importance of this tree species.

\section{Chiuri types}

From the survey, it was found that there are four types of the Chiuri grown in the study area based on the month of fruit maturity. The four types of the Chiure trees found in RRM are Asare, Shrawane, Bhadaure and Mansire (fruit harvesting in third, fourth, fifth and eighth month of Nepali Calendar) which are also named as Wayo, Lanyo, Titiye and Tomyo, respectively, in local Chepang language depending on the time of ripening of fruit. More than half (51\%) of respondents said there were four types of the Chiuri found in the area (Fig. 4) whereas other respondents responded that they had knowledge of one or two or three types of Chiuri (Fig. 4). There has been report of Diploknema butyraceae in the surveyed area but no other species (Govinda Ghimire, pers. comm., June 2021) . It may therefore be possible that the same species flowers and fruits at different time of the year depending on the elevation as is the case in other fruits. Alternatively, there may be another species of Chiuri in the survey area that is yet to be identified and reported.

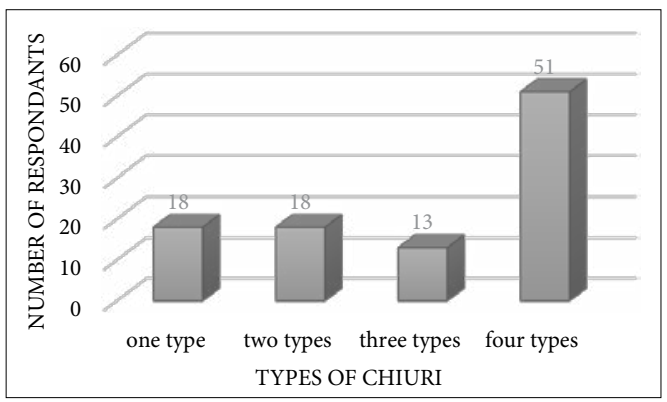

Figure 4: Types of Chiuri in RRM

\section{Influence of elevation on time of flowering, fruit ripening and defoliation in the surveyed area}

The flowering of Wayo, Lannyo and Titiya occurs in the month of November whereas the flowering of Tomyo occurs in the month of April (Manoj Praja, pers. comm., Nepal
Chepang Association-Raksirang, June 2021). However the survey revealed various times of fruit ripening at different elevations (Table 3). The first type Wayo ripened in June-July, followed by second type Lanyo ripened in JulyAugust, followed by third type Titiya ripened in September-October and the fourth type Tomyo ripened in November-December (Manoj Praja, pers. Comm., Nepal Chepang AssociationRaksirang, June 2021). The trend shows Chiuri types in the lower elevation fruits earlier than the higher elevation. It could be possible that they are different types, or it could be also possible that they are behaving differently in terms of the time of fruit ripening due to the elevation effect. This can be verified by further research of the morphological features of the Chiuri types, DNA analysis etc.

In contrast the timing of defoliation in all four types of Chiuri is different and not synchronized (Table 3 ). The two types such as Wayo and Tomyo, the leaves defoliate some months after fruit ripening, that is September and June respectively. In Lanyo, fruit matures in July-August and plant defoliates in August, similarly in Titiya; fruit matures in September-October and plant defoliates in October. However, in Wayo, fruit ripens in June-July and tree defoliates in September; after two months. Similarly, in Tomyo, fruit ripens in November-December and tree defoliates in June; after 6 months (Manoj Praja, pers. Comm., Nepal Chepang Association-Raksirang, June 2021). Thus, based on the defoliation pattern, these four types of Chiuri are behaving in three different ways. This perhaps is an evidence that they are different types and further investigation is necessary to understand if they are different types or same type. The present research however, revealed the time of defoliation and that is very important for determining appropriate timing for grafting of Chiuri with higher success. The use of grafted trees for commercial plantation of Chiuri could shorten the fruit bearing time from present (6-10 years) to 2-3 years. Foliated Chiuri 
Table 3: Influence of elevation on time to flowering, fruit ripening and time of defoliation in the surveyed area.

\begin{tabular}{|c|c|c|c|c|c|c|}
\hline $\begin{array}{l}\text { S. } \\
\text { No. }\end{array}$ & $\begin{array}{l}\text { Local } \\
\text { Name }\end{array}$ & $\begin{array}{c}\text { Name in } \\
\text { Report }\end{array}$ & $\begin{array}{c}\text { Ripening } \\
\text { time }\end{array}$ & English date & Defoliation & $\begin{array}{c}\text { Flowering } \\
\text { time }\end{array}$ \\
\hline 1 & Wayo & Asare & Jestha-Asar & June-July & $\begin{array}{l}\text { Beginning } \\
\text { September }\end{array}$ & November \\
\hline 2 & Lanyo & Shrawane & $\begin{array}{l}\text { Asar- } \\
\text { Shrawan }\end{array}$ & July-August & Mid-August & November \\
\hline 3 & Titiya & Bhadaure & Bhadra-Asoj & $\begin{array}{l}\text { September- } \\
\text { October }\end{array}$ & $\begin{array}{l}\text { End } \\
\text { October }\end{array}$ & November \\
\hline 4 & Tomyo & Mansire & $\begin{array}{l}\text { Mansir- } \\
\text { Paush }\end{array}$ & $\begin{array}{l}\text { November- } \\
\text { December }\end{array}$ & $\begin{array}{l}\text { Beginning } \\
\text { June }\end{array}$ & April \\
\hline
\end{tabular}

scion grafted during the month of January gave success rate of only $53 \%$ (Ramesh Subedi pers. comm., May 2021).

Seed size variation was observed between the two types of Chiuri. Wayo seed was found bigger $\left(1.75 \mathrm{~cm}^{2}\right)$ than Lanyo seeds $\left(1.40 \mathrm{~cm}^{2}\right)$.

\section{Number of seeds per kg of Chiuri:}

The number of seeds count per $\mathrm{kg}$ of the two types of Chiuri showed more seed count in Lanyo type (1176) as compared to Wayo type (1126) (Table 4). This is perhaps because the size of Wayo was bigger than Lanyo and hence number of Wayo seed count is less in a $\mathrm{kg}$ of seeds. The size of seeds and the kernel could play an important role on yield of Chiuri butter (gheu).

Table 4: Number of seeds per kg of Chiuri

\begin{tabular}{ll}
\hline \multicolumn{1}{c}{ Type } & Number of seeds \\
\hline Wayo & 1126 \\
Langyo & 1176 \\
\hline
\end{tabular}

\section{Production of Chiuri seed in Khoria and Bari}

Based on the survey, $22 \%$ of respondents said they harvest more than $90 \mathrm{~kg}$ of Chiuri seeds from Khoria whereas only $9 \%$ of respondents harvested the same quantity of Chiuri seeds from Bari. The lesser number of respondents harvesting more than $90 \mathrm{~kg}$ seeds in Bari land could be because of bigger and old trees in the Khoria in comparision to Bari. The concept of growing Chiuri trees in Bari is not very old. Similarly, $74 \%$ of respondents harvested up to 90 $\mathrm{kg}$ of Chiuri seeds from Khoria and $4 \%$ did not harvested the seeds from Khoria. In contrast, all the respondents said they harvest Chiuri seeds from their Bari (Table 5). Thirty eight percent respondents in 30-60 kg seed harvest category from Bari is higher than Khoria (8\%) suggesting Chiuri plantation in Bari land is in the increasing trend.

Table 5: Quantity of Chiuri seeds produced in Khoria and Bari

\begin{tabular}{|c|c|c|}
\hline $\begin{array}{c}\text { Quantity of Chiuri seeds } \\
\text { in kg }\end{array}$ & Khoria & Bari \\
\hline no harvest & 4 & 0 \\
\hline $0-30$ & 22 & 14 \\
\hline $30-60$ & 8 & 38 \\
\hline $60-90$ & 44 & 39 \\
\hline 90 above & 22 & 9 \\
\hline Total & 100 & 100 \\
\hline
\end{tabular}

\section{Conclusion}

It is evident from the survey that Chiuri is growing from 300 masl to 1500 masl elevation in the municipality. Most of them have Chiuri older than 30 years of age and their khoria facing south direction. The Chiuri takes 6-10 years' time to start fruiting from seeding after plantation. Four types of Chiuri namely Wayo, Lanyo, Titiye and Tomyo are found in 
RRM. Based on the survey, Wayo and Lanyo Chiuri were found in lower elevation whereas Titiya and Tomyo Chiuri were found in higher elevation. Time of fruiting is synchronized with lower elevation trees fruiting earlier than higher elevation trees. However, the same pattern is not observed with regards to defoliation. Based on the survey conducted, it is recommended to estimate number of Chiuri trees of various ages within the RRM to predict yield of seeds, plan future potential plantation program and assess to determine varietal difference. Further study on the morphological and molecular characterization is necessary to further confirm the different types of Chiuri as documented. The elite types as per the ecological preference shall be propagated to maintain the true characters of the mother plants. The availability of grafted plants of superior mother types and trees could be the beginning in improving the production system of Chiuri in Nepal.

\section{Acknowledgements}

We would like to acknowledge National Forum for Advocacy, Nepal for giving us opportunities by providing manpower to conduct this research. We are grateful to all the respondents and local people who coordinated during our survey. We are also thankful to the social mobilizers of NAFAN (Ramsharan Dong, Kamana Praja and Hukum Bahadur Malla) who conducted the survey even during the harsh condition of rainy season and Covid-19 pandemic by keeping social distancing. Finally, we thank all the people who directly or indirectly supported to conduct this research. 


\section{References}

Bhattarai, T. R. (1995). Chepangs: Status, efforts and issues: A Syo's perspective. In T. R. Bhattarai, Chepang Resources and Development (pp. 5-11). Kathmandu: Netherlands Development Organisation in Nepal $(\mathrm{SNV}) /$ School for Ecology, Agriculture and Community Works (SEACOW).

Chhetri, N. S., Ghimire, S., Gribnau, C., Pradhan, S., \& Rana, S. (1997). Can Orange Trees Bloom on a Barren Land. Identification of development potentials of Praja communities in Chitwan District. Kathmandu: The Netherlands Development Organization (SNV).

Chikanbanjar, R., Pun, U., Bhattarai, B. P., \& Kunwar, R. M. (2021). Chiuri (Diploknema butyracea (Roxb.) H.J. Lam): A tree species for improving livelihood of Chepang in Makwanpur, Central Nepal. Ethnobotany Research and Applications, 21(1), 1-11. doi:10.32859/era.21.15.1-11

MEDEP. (2010). Resource Analysis of Chyuri (Aesandra butyracea) in Nepal. Kathmandu: Micro-Enterprise Development Programme (MEDEP-NEP 08/006).

MEDEP. (2014). Micro Enterprise Development in Nepal Potentials, Achievements and Impacts. Kathmandu: Micro Enterprise Development Programme (MEDEP IV), GoN-Ministry of Industry/UNDP.

Practical Action. (2010). Chiuri - the Butter Tree of Nepal (Practical Action Brief). Retrieved June 12, 2021, from Appropedia: https://www.
appropedia.org/Chiuri_-_the_Butter_Tree_ of_Nepal_(Practical_Action_Brief)

Raksirang Rural Municipality. (2019). Rural Municipality Profile: Raksirang Rural Municipality. Chainpur: Raksirang Rural Municipality.

Rijal , A. (2011). Surviving on Knowledge: Ethnobotany of Chepang community from mid-hills of Nepal. Ethnobotany Research and Applications, 9, 181-215. doi:10.17348/ era.9.0.181-215

Shakya, M. R. (2000). Chepangs and Chiuri, the Use of Non Timber Forest Products in Nepal. Food Chain, 26, 3-5

Shukla, A. (2017). Fate of Chiuri in Nepal. Retrieved from Aruna Shukla, Treasures of Nepal: http://arunashukla.com/fate-chiuri-nepal/

Thapa, S. (2019). Chiuri: A review on its multipurpose use in Nepal. International Journal of Agriculture and Environment Research, 5(4), 527-538.

Timilsina, K., \& Mishra-Tripathi, K. (2019). Effect of altitude and fruit bearing position on physical quality attributes of mandarin (Citrus reticulata Blanco) in Kavre, Nepal. International Journal of Horticulture, Agriculture and Food Science, 3(4), 232-242.

Whiley, A. W., Rasmussen, T. S., Saranath, J. B., \& Wolstenholme, B. N. (1989). Effect of temperature on growth, dry matter production and starch accumulation in ten mango (Mangifera indica L.) cultivars. Journal of Horticultural Science, 64(6), 753765 . 